Af Yvonne Mørck og

Bente Rosenbeck

Artiklen prosentever og diskuterer forskellige aspekter af klasserejsebegrebet. Der inddrages personlige beretninger om 'rejseerfaringer' fra konsforskere $i$ dag og fra forste generations kvindelige akademikere, samt engelske arbejderklassepigers erfaringer med klasserejse i 1950'erne og etniske minoriteters erfaringer $i$ dag. Intentionen med bidraget er sailedes at belyse sammenvevningen af kon, klasse og etnicitet $i$ både et historisk og aktuelt perspektiv i forhold til uddannelse.

\section{Rejser og
forandring: \\ Rejser og
forandring: \\ Intersektioner af
, køn og etnicitet \\ Intersektioner af
klasse, køn og etnicitet}


'arbejderklasse' (Mahony og Zmroczek 1997: 2). Denne problematik er aktuel både i den danske og den internationale debat om sammenvævning af kategorier som køn, klasse og etnicitet. Da klasserejsebegrebet kun i begrænset omfang er udfoldet i en dansk kontekst i modsætning til en svensk og en norsk, vil vi i denne artikel præsentere og diskutere forskellige aspekter af dette begreb.

Artiklen indledes med to nulevende kvindelige klasserejsendes beskrivelser af deres færd ind i akademia. Derefter sættes der fokus på, hvad vi betegner en 'kvindelig kønsrejse' eksemplificeret ved de første kvindelige akademikeres adgang til at studere ved Københavns Universitet fra 1875. Endelig beskrives en gruppe piger fra 1940' -1950'ernes East End i London, som fik en længere skolegang, og de repræsenterer både en klasse- og kønsrejse. Området blev igen genstand for en undersøgelse i 1990'erne, og i dette 'nye East End' træeder etnicitetsaspektet - i samspil med klasse og køn - tydeligt frem. Intentionen er således at belyse sammenvæuningen af køn, klasse og etnicitet $\mathrm{i}$ både et historisk og aktuelt perspektiv set i forhold til uddannelse.

Selvom der kan synes at være langt fra kvindelige akademikere til arbejderklassepiger og etniske minoritetsunge, synes der at være nogle fælles erfaringer og oplevelser af at stå udenfor.

\section{REJSEERFARINGER - OG ØNSKE OM FORANDRINGER}

Dét, vi var vidne til ved præsentationen af Class Matters, handlede om følelser og om de smertepunkter, der kan være forbundet med at møde en ny kultur og blive fremmed over for den, man kommer fra - og måske ende med ikke at høre hjemme nogen steder, det vil sige at være en slags hjemløs. At være 'klasserejsende' er af den svenske sociolog Mats Trondman blevet defineret som at være opvokset i én type af miljø og gennem især uddannelse bevæge sig ind i og leve sit liv $\mathrm{i}$ andre miljøer samtidig med at kontakten til dele af oprindelsesmiljøet, især den nære familie, bevares (Trondman 1994).

Forfatterne bag Class Matters har alle gennemført en klasserejse. En af bidragsyderne er den engelske sociolog Beverly Skeggs, som nok er den af forfatterne, der efterfølgende er blevet mest kendt bl.a. på grund af bogen Formations of Class and Gender: Becoming Respectable fra 1997. Her analyserer hun arbejderklassekvinders ihærdighed med at blive respektable; bestræbelser, der er kendetegnet af 'dis-identifikation', idet respektabilitet knyttes til en afstandtagen til det oprindelige miljø. Samtidig indebærer denne dis-identifikation at arbejderklassekvinder sjældent føler sig trygge og kan 'hvile' i sig selv. Samme oplevelse af 'dis-identifikation' kan udlæses af Skeggs egen historie.

Skeggs har tydeligvis været fornyer ved at genindsætte klasseperspektivet på en ny måde $i$ analyser af køn og seksualitet, det vil sige at hun har formået at analysere kombinationen af flere dominansformer. Hun har kort og godt haft succes, men som hendes beretning i Class Matters viser, har hendes rejse ikke altid været lige let.

Ifølge hendes egne oplevelser, som er beskrevet i en kortfattet biografisk skitse, var rejsen ind i akademikerverdenen egentlig ikke den sværeste. En kombination af held og kulturel og social kapital gjorde det muligt for hende at påbegynde en højere uddannelse. Faderen var interesseret i politik, hvilket befordrede en interesse, som var omsættelig i sociologi og politik. Hun havde således noget med hjemmefra, og så havde hun høje karakterer (Skeggs 1997). Men hun manglede også noget - og rejsen kostede. Skeggs fortæller bl.a., at mens middelklassens børn voksede op og læste bøger, var hun sammen med sine veninder, så hun manglede en masse viden. Selv om hun klarede sig godt, var hun 'mærket' af arbejderklassen, hvilket skabte en vis form for usikkerhed. Hun følte sig forkert på 
trods af, at hun udadtil var skarp og kløgtig. Hun ville frem og have akademiske grader og titler, og det lykkedes også for hende. Men hun fik også problemer med sin familie og sine arbejderklassevenner, som så hendes nye middelklassevaner som tegn på, at hun stræbte opad (Skeggs 1997: 133). Selv nu føler Skeggs sig som én, der 'passerer' som noget hun ikke er, og hun skriver, at hun altid er bange for at blive afsløret: "... I feel a fraud, I feel that one day somebody will find out that I should not really be here" (Skeggs 1997: 133).

Efter Skeggs selv er 'blevet til noget', forsøger hun at hjxlpe de nye studerende og nytilkomne, selvom hun er ambivalent: "We can give them skills, the language and the technical competence, but can we give them the feelings of security and entitlement?" (Skeggs 1997: 134). Så der udkæmpes stadig klassekampe i det feministiske undervisningsrum. Skeggs mener, at hun burde glæde sig over at kunne bidrage til at integrere andre, som føler sig udenfor, fordi de kommer fra en anden klasse. Hun ved jo, hvorfor hun og andre har disse klasserejserelaterede problemer, men lige meget hjælper det på hendes egen følelse af hjemløshed: “... there is nowhere else to go or to be. My mother still thinks I'm a disappointment" (Skeggs 1997: 134).

Skeggs' historie fortæller primært om omkostninger ved en klasserejse. Mærkeligt nok synes disse omkostninger at have været mindre for den afro-amerikanske kønsforsker, som kalder sig bell hooks på trods af, at rejsen for hende har været endnu længere. Hun kommer nemlig fra en fattig, afroamerikansk og dysfunktionel arbejderklassefamilie i det sydlige USA, det vil sige en verden dybt præget af klassemæssig og racial apartheid. Måske fordi hun allerede i en meget ung alder blev klar over, at hun ville skrive, har hun haft en drivkraft, som har holdt hende oppe - også da hun kom på universitetet, hvilket langt fra var en positiv oplevelse. Hun synes ikke, at hun blev hørt. Ingen andre havde forståelse for, at det ikke kun handlede om køn, men også om klasse og 'race' skriver hun i sin selvbiografi Wounds of Passion. A Writing Life (hooks 1997: 207). Bl.a. måtte hun høre på udtalelser fra hvide kvindelige medstuderende om, at afro-amerikanske kvinder altid havde været mere frie end hvide kvinder, fordi sorte kvinder havde arbejdet. Men, som hooks påpeger, så ligger friheden ikke i dét at arbejde. Hverken for afro-amerikanske kvindelige slaver eller for fattige afro-amerikanske kvinder efter slaveriet har arbejde været ensbetydende med frihed.

hooks har taget nogle andre valg end Skeggs. hooks valgte at skrive bøger, som også henvender sig til en ikke-akademisk læserkreds. Derfor findes der ingen fodnoter i hendes bøger, og hun foretrækker at undervise på City College i New York, hvor der kommer 'voksne' studerende, der ofte også er klasserejsende. Ligesom Skeggs har hun været fornyer inden for kvinde- og kønsforskningen dels ved at sætte etnicitet og 'race' på dagsordenen og dels ved at understrege nødvendigheden af et intersektionalitetsperspektiv, det vil sige at sammentænke flere ulighedssystemer som klasse, køn og etnicitet. For både Skeggs og hooks har netop sammenvævningen af deres respektive klassebaggrund, køn, etnicitet og 'race' haft en konstruktiv og kreativ indflydelse på deres forskning, hvorved de har banet vejen for anderledes og subversive videnskabelige optikker. Begge har haft en markant position inden for de sidste års kønsteoretiske diskussioner. Vi har anvendt deres personlige og faglige historier til at illustrere, hvordan erfaringer med at være Den Anden kan bidrage til en øget forståelse af, hvad de komplekse rejser som social mobilitet via uddannelse kan indebære.

Den engelske forsker Valerie Hey opfatter da også feministiske arbejderklasseakademikere som queer subjekter, der kan sætte spørgsmålstegn ved normerne i akademia. Derfor er den særlige 'klasserejselitteratur', som bogen Class matters tilhører og hvori der insisteres på, at det personlige er 
politisk, vigtig, skriver Hey (2003). Det er en litteratur, som kan fremkalde visioner om forandring. Mens klasse måske nok betød for meget i 1970'erne, er det kommet til at betyde for lidt ifølge Hey. Der har været en tendens til at erklære klasseaspektet for dødt, men en genoplivning af begrebet i relation til uddannelse og forskning kan synliggøre skjulte strukturer, der bl.a. indebærer, at klasserejsende føler en manglende identifikation og en vis hjemløshed. Det er således vigtigt at overveje de teoretiske implikationer af disse klasserejse-fortællinger, hævder Hey (Hey 2003: 319). De kan bidrage til en videnskabskritik og indeholde et videnskabsforandrende potentiale.

hooks og Skeggs tilhører en fjerde eller femte generation af akademikerkvinder, hvor kvinder er kommet ind i højere uddannelse i stort tal, og hvor et nyt forskningsområde i køn er kommet til. For den første generation af kvindelige akademikere var det ikke, som vi viser i det følgende, deres klassebaggrund, som var et problem men deres køn.

\section{'KVINDELIGE KØNSREJSENDE':}

\section{DE FØRSTE KVINDELIGE AKADEMIKERE}

Da den svenske etnolog Jonas Frykman undersøgte svenske intellektuelle fra arbejderog lavere middelklasse født omkring 1920 for bl.a. at studere klassebaggrund, viste det sig, at der kun var ganske få kvinder iblandt disse (Frykman 1991). Kvinder blev nemlig først klasserejsende med 1960'ernes og 1970'ernes uddannelseseksplosion. Første generation af kvinder, der bevægede sig ind $\mathrm{i}$ universitetsverdenen fra 1875, var først og fremmest 'kvindelige kønsrejsende'. For mænd fra borgerskabet var universitetet nemlig en selvfølgelig institution, mens det for de første kvinder, som også kom fra borgerskabet, var noget af en rejse at begive sig ind $\mathrm{i}$ en institution, som var totalt maskulin.

Da den første kvinde i Danmark, den se- nere læge Nielsine Nielsen, søgte om optagelse på universitetet i begyndelsen af 1870'erne, fandt man ud af, at der ikke eksisterede noget forbud mod, at kvinder kunne studere. Optaget blev de, og den første generation af akademikerkvinder foretog altså for de flestes vedkommende ikke en klasserejse, men en 'kønsrejse'. De kom fra borgerlige miljøer og medbragte derfor en del kulturel, social og økonomisk kapital. Kvinderne kom faktisk fra bedre stillede og mere læsevante miljøer end deres mandlige studiekammerater, hvilket indebar, at de havde mere kulturel kapital end mænd ifølge en bourdieusk optik. De første kvindelige studenter havde også et højt karaktergennemsnit (Manniche 1983-85: 207, 214).

Sådanne forudsætninger burde pege mod en kommende forskerkarriere, men sådan var det langtfra. Kvinder har i uddannelsessystemet været udsat for diskrimination og en systematisk negativ særbehandling på grund af deres køn. De var i Bourdieus forstand udsat for symbolsk vold (Bourdieu 1999). Universiteterne var indgangsport til rigets højeste stillinger, og her var kvinder ikke velkomne. Det akademiske borgerskab var maskulint, og kvinder var nærmest ikke eksisterende (Rosenbeck 2008). Adgangen til at studere var ikke ensbetydende med adgangen til at forske. På universitetet havde man faktisk slet ikke forestillet sig, at akademiske studier skulle føre til forskning for kvinders vedkommende. De første 25 år (før 1903) havde de heller ikke ret til at tage den adgangsgivende studentereksamen undtagen i privat regi, og derefter varede det yderligere 20 år, inden de fik adgang til offentlige embeder og erhverv med vedtagelsen af loven $\mathrm{i}$ 1921, der fastslog kønnenes lige adgang til alle offentlige tjenestestillinger og erhverv med undtagelse af de gejstlige og de militære (Alenius et al. 1994).

Det var mærkeligt nok ikke religiøse argumenter, som blev brugt i modstanden mod kvinders ret til at studere, men seku- 
lære og videnskabelige. Der blev ikke refereret til Biblen og Gud, men til naturen. Samtidig med at kvinder overalt i den vestlige verden fik lov til at studere på universitetet, gennemgik videnskaben en moderniseringsproces. Den moderne videnskab var meget optaget af kønnet, og bidrog til at biologisere og naturalisere især kvindekønnet. Her opstod opfattelsen af, at kvinders reproduktive evner stod i modsætning til intellektualitet. Professionalisering og modernisering af videnskaben fremmede studier, som kunne bruges som bevis på, at kvinder ved at være tilknyttet det private ikke var i stand til at deltage i politik, på arbejdsmarkedet eller producere intellektuelt arbejde. Kvinder blev determineret af deres biologi (Rosenbeck 1987). Det var unaturligt, at kvinder skulle studere. Kvinder blev forvist til familien og privatsfæren. Kvindens egentlig kald lå i hjemmet, og det kunne være til fare for samfundet at rive hende ud af familiens skød, lød et af argumenterne fra Det teologiske Fakultet imod at optage kvinder på universitetet. Som en undtagelse men ikke som en ret eller som en regel kunne der ifølge fakultetet forekomme tilfælde, hvor "en sjælden og mærkelig Begavelse kræver Virksomhed i videre Kredse" (Jacobsen 1925: 131).

Modsætningen privat-offentlig er således vigtig for at forstå de barrierer, der eksisterede $\mathrm{i}$ videnskaben i forhold til kvinder. Ved at repræsentere det private blev kvinder set i modsætning til det videnskabelige. Fremstillingen af kvinden i videnskaben var en parallel til billedet af kvinden i det offentlige rum; de var per definition prostituerede, dvs. 'offentlige kvinder'. Kvinder hørte derfor heller ikke hjemme på et universitet, som var et offentligt rum. Samtidig med at videnskaben blev professionaliseret, foregik der en intimiseringsproces, hvor moderskabet fik tillagt større værdi, og familien blev privatiseret. Kvinden blev dømt ude af den offentlige sfære og forvist til den private sfære (Rosenbeck 1987, 2008).

I 1875 var det kommet så langt, at kvin- der i Danmark kunne få lov til at blive undervist og at lære noget, men det næste skridt, som ledte ind i den institutionaliserede forskning, var mere problematisk. Eksklusionsprocesserne fortsatte. $\mathrm{Nu}$ var det ikke længere et spørgsmål om at lære kvinderne noget; nu ville eller kunne de selv forvalte og udvikle kundskab på selvstændig vis. Det truede selve fundamentet i den konstruktion af mandlighed og kvindelighed, som samfundets kønssystem hvilede på. Hvis det viste sig, at kreativitet, abstrakt tænkning og formåen til konstruktiv videnskabelighed var noget, som kvinder delte med mænd, så risikerede man, at grænserne mellem kønnene blev nedbrudt. Er det måske her, at vi skal finde årsagen til modstanden mod de kvindelige forskere?

Der var flere niveauer i modstanden mod, at kvinder skulle forske. For det første var det svært for kvinder at få en adgangsgivende eksamen. Dernæst kom vanskelighederne med at blive accepteret som forsker, og endelig var det også svært at få lov til at anvende kundskaben i samfundets tjeneste, det vil sige at få et embede. Kvinder har således nærmest været på 'tålt ophold' på universiteterne. De har muligvis også haft svært ved at knække den maskuline akademiske kode.

De nytilkomne kvinder på universitetet havde $\mathrm{i}$ den første fase fra $1875 \mathrm{og}$ frem til 1970 ikke de store chancer for at sætte deres præg på institutionen. Dette ændrede sig først med 1960'ernes uddannelseseksplosion og 1970'ernes kvindebevægelse, som satte kvindespørgsmålet på den akademiske dagsorden. Skeggs og hooks er en del af denne udvikling, hvor det med Bourdieus teminologi lykkedes de nytilkomne, det vil sige de dominerede, at føre en modstrategi eller subversiv strategi (Bourdieu 1975). De første generationer af kvinder på universitetet, nemlig de 'kvindelige kønsrejsende', tilpassede sig således den dominerende ideologi og nedtonede den subversive strategi. Mens 1870'ernes kvindebevægelse bidrog til at åbne universiteterne 
for kvinder, var 1970'ernes kvindebevægelse med til at forandre det faglige indhold. Kroppen, kønnet, det private og seksualiteten var noget af det nye, som kom til. Og med bl.a. hooks og Skeggs også klasse-, etnicitets- og 'race'aspekterne. I modsætning til den første generation af kvindelige akademikere var de nemlig både køns- og klasserejsende.

\section{ERFARINGER FRA DET GAMLE OG DET NYE EAST END}

Hvordan kom arbejderklassepiger overhovedet i gang med en klasserejse, og hvordan har nogle piger oplevet denne rejse? I dette afsnit skal vi følge nogle af de meget tidlige kvindelige køns- og klasserejsende fra 1950'erne; et årti før uddannelseseksplosionen rigtigt satte ind. Materialet er hentet fra de to engelske sociologer $\mathrm{Mi}$ chael Young og Peter Willmotts analyse af Bethnal Green, som var et klassisk arbejderklassekvarter i Londons East End, som blev brudt op, da mange familier som følge af efterkrigstidens boligpolitik flyttede til store nybyggede 'housing estates' i Londons forstæder (Young and Wilmott 1990, org. 1957). Beretninger fra de på interviewtidspunktet voksne kvinder viser, at de som piger blev isolerede i relation til deres oprindelige miljø. ${ }^{1}$ Det var mest mødrene, der støttede døtrene i at gå videre, mens fædrene var mere forbeholdne. Nogle voksne i nærmiljøet så skævt til disse piger, som gjorde noget andet end majoriteten, som forlod skolen i en ung alder og tog et ufaglært arbejde. Der rådede således et stærkt konformitetspres. Pigernes forhold til de andre børn blev også berørt af deres skolevalg. Pigerne mistede deres venner, som havde været deres tidligere klassekammerater, fordi de var de eneste i gaden, der gik i 'grammar school'. Når pigerne kom hjem fra skole, skulle de forberede lektierne og kunne derfor ikke deltage i hverken gadens aktiviteter eller i husarbejde. Pigerne gik også i særlige skoleuniformer, som afslørede dem som 'anderledes' end de andre børn, hvilket medførte negative bemærkninger. Såvel voksne som børn i lokalområdet udviste således fjendtlighed over for dem.

En anden form for klassepres, som pigerne blev udsat for, kom fra andre elever, som var bedre økonomisk og socio-kulturelt stillede. Piger fra mere velbeslåede hjem havde f.eks. råd til dyre kjoler til skolefester, ligesom deres forældre selv betalte for, at deres børn gik på skolen, mens pigerne fra East End havde fripladser. Selvom Bethnal Green-pigerne efterhånden blev tosprogede i den forstand, at de talte arbejderklasselondonsk ('cockney') i hjemmemiljøet og standard engelsk i skolen, følte de sig alligevel akavede, utilpasse og mindreværdige i forhold til eleverne fra bedrestillede miljøer. Og hvis de i hjemmemiljøet talte, som det blev forventet i skolen, blev de anset for snobbede (Young og Willmott 1990: 176179). De kvindelige køns- og klasserejsendes situation var således præget af ambivalens.

Efter 1950'erne skete der imidlertid store forandringer med befolkningssammensætningen. Før da var der få ikke-hvide beboere i East End, hvilket afspejles i bogen fra 1957, da ingen med etnisk minoritetsbaggrund deltog. I en opfølgende undersøgelse fra 1992-1993 viste et 'nyt East End' sig, idet mennesker med rødder i Bangladesh udgjorde $40 \%$ af husholdsbeboerne i undersøgelsen, mens hvide eller etniske britere udgjorde 48 \% (Dench, Gavron og Young 2006: 236). ${ }^{2}$

Tidligere udspillede konflikter mellem beboerne i East End og nytilkomne sig i relation til konkurrence på arbejdsmarkedet. Det gælder stadig, men konkurrencen om arbejde bliver i stadig højere grad erstattet af konkurrence om adgang til velfærdsstøtte og offentlig service (Dench, Gavron og Young 2006: 4). Et af de væsentligste konfliktfelter mellem den etniske majoritetsbefolkning og de etniske minoriteter i East End er således skolesystemet. Det dominerende syn på skolegang og uddannelse i 
East End har traditionelt været, at den viden, man kunne opnå via skolegang, ikke spillede nogen større rolle. Hvad børnene lærte ud over at læse og skrive blev ikke anset for noget, man kunne bruge til noget. For drengenes vedkommende skulle de tjene deres penge ved manuelt arbejde, det vil sige at fysisk styrke og sejhed var afgørende. Denne ligegyldighed over for uddannelse blandt etniske majoritetsfamilier gælder stadig for mange. Samtidig er der kommet et øget antal etniske minoritetselever i skolerne, især børn med rødder i Bangladesh, som har et positivt syn på skolesystemet.

På trods af en række barrierer såsom sparsomme engelskkundskaber ved skolestart, at mange af børnene tages ud af skolen i længere perioder for at være i Bangladesh, og at familierne bor i overbefolkede boliger klarer mange af børnene sig godt fagligt - ikke mindst pigerne. Forældres støtte til uddannelsesprojektet er en vigtig faktor for denne succes: De vurderer, at uddannelse er vejen til et bedre liv end de selv har haft (mulighed for), det vil sige de værdsætter uddannelse. Børnene er bedre disciplinerede og medgørlige end hvide børn, hvilket afspejles i deres faglige resultater (Dench, Gavron og Young 2006: 139-141). Især pigerne klarer sig godt, men også hvide piger klarer sig bedre end hvide drenge i de lokale skoler (Dench, Gavron og Young 2006: 141-142).

Der tegner sig således et meget komplekst billede af forholdet mellem klasse, køn og etnicitet i dette lokalområde præget af stor diversitet. Det er dog slående, at både etniske majoritets- og minoritetspiger klarer sig bedre fagligt end drengene. Sa skønt der er væsentlige barrierer for deres rejser, ser mange piger ud til at udnytte rejsemulighederne, når de viser sig.

\section{AT REJSE OG AT FORANDRE - FÆLLES REJSEERFARINGER}

Den norske antropolog Marianne Gullestad hører sammen med Mats Trondman til de fă, som har arbejdet mere teoretisk med klasserejsebegrebet $\mathrm{i}$ en nordisk sammenhæng (Gullestad 2002; se også Wennerstrøm 2003; Mørck 2006, 2008, 2009). Hun bruger begrebet som en paraplybetegnelse, når hun påpeger, at mennesker har foretaget forskellige slags rejser både historisk og i nutiden: Rejser mellem sociale grupper baseret på bl.a. klasse, etnicitet eller religion og mellem geografiske steder såsom land, by, regioner, nationer og kontinenter.

Alle disse rejser indebærer en vifte af 'kulturmøder', idet den rejsende møder mennesker med anden levevis, andre kulturelle og sproglige koder, andre værdier, normer, erfaringer og fortolkningsrammer end vedkommende selv. En klasserejse har således identitetstransformerende konsekvenser for via 'kulturmøderne' udvikles både nye selvopfattelser og nye kultur- og handlemønstre (Gullestad 2002). Kultur og identitet får således synkretistiske former og udtryk. I denne proces udvikles der sociokulturelle forskelle mellem de mennesker, der har foretaget en klasserejse og de, der ikke har, hvad Bourdieu betegner som 'arvens modsigelser' (Bourdieu et al. 1999). Dette kan føre til, at sidstnævnte føler sig 'forladte', og derfor kan de være fordømmende over for den klasserejsende, hvilket kan være en smertefuld erfaring for den rejsende, som måske tilmed oplever, at han/ hun ikke bliver fuldt accepteret $\mathrm{i}$ det nye miljø (Gullestad 2002). Set fra hjemmemiljøets side er den klasserejsende et tegn på en mislykket socialisation (Frykman 1991: 108). En klasserejse er, som vore eksempler har vist, fyldt med såvel dilemmaer, ambivalenser og smertefulde dimensioner som med kreativitet, fordele og glæder.

En væsentlig komponent i menneskers liv, som både påvirker og bliver påvirket af en klasserejse, er køn. Det er imidlertid vigtigt dels at være opmærksom på, at rejserne former sig forskelligt afhængigt af $\mathrm{k} ø \mathrm{n}$ og dels, at forestillinger om maskulinitet og femininitet er på spil for begge køn uanset et- 
nisk baggrund, når man foretager en klasserejse.

Kvinder synes at have spillet en særlig aktiv rolle i klasserejseprojektet, idet det ofte har været mødrene, som har presset på for at sønner og i nogle tilfælde også døtre skulle have en uddannelse (Frykman 1991; Ambjörnsson 1996; Mahony og Zmroczek 1997). Mødrene har mere eller mindre bevidst arbejdet for, at sønnerne ikke skulle blive som deres fædre, og de har styret sønnernes interesser i 'feminin' retning. Hvis drengen (efter)lignede faderen for meget f.eks. i adfærd og måder at gå og tale på, blev der ingen klasserejse; han skulle tage afstand fra faderen og nærme sig det 'kvindelige' og gå uddannelsens vej.

I arbejderklassemiljøer har det historisk været udbredt at forbinde det boglige med det feminine. Det indebar, at unge mænd, som havde boglige interesser eller som studerede især humanistiske emner blev opfattet som nogle, der mistede deres maskulinitet. Et eksempel på det fænomen findes $\mathrm{i}$ Ronny Ambjörnssons erindringsbog Mitt förnamn är Ronny, hvor han fortæller om sin klassserejse (Ambjörnsson 1996). Han er født i 1930'erne og opvokset i et arbejderklassekvarter i Gøteborg og endte som professor i idehistorie i Umeå. Faderen syntes imidlertid, at han skulle være fysiker eller ingeniør. Ambjörnsson var dog mere interesseret i de humanistiske fag, og han var omkring antropologi og nordiske sprog- og litteraturstudier, før han landede på ide- og uddannelseshistorie. Han fortæller, at dette fag lå faderens interesse for naturvidenskabens verden nærmest. Dét at læse skønlitteratur fremstod til gengæld for faderen som for feminint. Skønlitteratur var fyldt med følelser “... och en man som vistades för länge $\mathrm{i}$ känslornas värld risikerade att förvandlas till ett slags neutrum i könslig bemärkelse, varken man eller kvinna, en varelse stadd i förändring" (Ambjörnsson 1996: 68). Både kvinder og mænd må altså forholde sig til forestillinger om køn, når de fortager en klasserejse. I disse år tyder me- get på, at det er etniske minoritetsdrenge i f.eks. England og Danmark, som har det sværest i uddannelsessystemet, og det kan ud over klasse og etnicitet have noget med køn at gøre (se f.eks. Mørck 2003).

Både i forskningslitteratur om klasserejsende med etnisk majoritetsbaggrund og om etniske minoritetsunge $i$ vesten og $i$ selvbiografiske beretninger fra disse grupper tales der om, at man løsrives fra sine oprindelige rødder, og at man ofte oplever social isolation og hjemløshed. Der er en følelse af at stå 'uden for' og at leve et liv i eksil. De rejsende betaler en pris, men de făr også kendskab til flere socio-kulturelle arenaer, de kan være kreative med identifikation og udtryk, og de er potentielle bærere af og repræsentanter for fremskridt og forandring. Typisk indebærer rejserne en bevægelse fra land til storby og dermed også nye vilkår $\mathrm{i}$ forhold til identifikation, arbejde og underholdning.

En fordel ved rejsemetaforen er, at den favner forskellige slags rejser og rejsende, herunder kvindelige kønsrejsende og klasserejsende. I relation til forskning om social mobilitet bidrager klasserejsebegrebet med en øget indsigt i følelses- og identitetsmæssige dimensioner ved rejsen, og der tages ofte afsæt i et inde-fra-perspektiv. Når en klasserejsetilgang knyttes sammen med et intersektionalitetsperspektiv, hvor der opereres med flere sammenvævede dominanskomponenter, kan der produceres stadig mere kompleksitetsudvidende analyser. Endelig giver klasserejseperspektivet mulighed for at sætte fokus på det processuelle ved rejsen. Man kan nemlig indfange både dét de klasserejsende bringer med sig på rejsen, hvordan de oplever de kontekster som de bevæger sig ind, og man kan få blik for og anerkende, at de bidrager med noget nyt f.eks. andre erfaringer og perspektiver.

Det fremgår af vores forskellige empiriske eksempler, at der er en række fællestræk ved at være klasserejsende uanset køn og etnicitet. Den rejsende begiver sig ud på mindst tre rejser. For det første en 'sproglig 
rejse', da samfundsgrupper ikke blot har forskellige sprogkoder afhængig af bl.a. socialt, geografisk og (sub)kulturelt tilhørsforhold men også kan have forskellige modersmål. Denne rejse afspejles f.eks. i det sproglige skifte arbejderklassepigerne fra East End fortog, når de var henholdsvis hjemme og i skolen, og det sprogskifte som etniske minoritetsbørn i det 'nye East End' må igennem for at klare sig i skolen. Endelig må alle klasserejsende bevæge sig fra et hverdagssprog til et fagsprog eller akademisk præget sprog. For det andet foretages der en rejse gennem (delvis) forskellige måder at tænke, handle og fortolke på, idet den rejsende konfronteres med andre levemåder, koder, værdier og normer (f.eks. Skeggs' og hooks' erfaringer). For det tredje indebærer rejsen, at der dannes 'brobyggende netværker', det vil sige relationer der rækker ud over bånd til familie, venner og velkendte miljøer. Den rejsende erfarer, at 'afgrænsende netværker' og relationer til nogle der 'ligner' den rejsende selv, ikke er tilstrækkelige til at få succes med rejsen (Putnam 2007; se Mørck 2006 for en uddybning af de tre rejser).

Som vi har vist er dét at foretage en klasserejse del af en større moderniseringsproces og et livsvilkår for mange. Det interessante er imidlertid at finde ud af, hvordan de klasserejsende kan integreres i uddannelsessystemet og om der med de klasserejsende kan inddrages andre erfaringer end de, der traditionelt har været en del af uddannelsessystemet - fra folkeskole til universitet.

\section{Noter}

1. Undersøgelsen rummer ingen oplysninger om drenge, der gik videre i tilsvarende skoler. Børnene blev delt, når de var 11 år.

2. Forfatterne anvender betegnelserne 'hvide' og 'hvide børn', som vi bruger synonymt med hhv. etniske britere og etniske majoritetsbørn.

\section{LITTERATUR}

- Alenius, Marianne, Nanna Damsholt, Bente Rosenbeck (red.) (1994): Clios dotre gennem hundrede àr. I anledning af historikeren Anna Hudes disputats. Museum Tusculanum, København.

- Ambjörnsson, Ronny (1996): Mitt förnamn är Ronny. Bonnier, Stockholm.

- Bourdieu, Pierre (1975): The specificity of the scientific field and the social conditions of the programs of reason. Social Science Information 14/6. - Bourdieu, Pierre (1999): Den maskuline dominans. Tiderne skrifter, København.

- Bourdieu, Pierre et al. (1999): The Weight of the World. Social Suffering in Contemporary Society. Polity Press, Cambridge.

- Dench, Geoff, Gavron, Kate and Young, Michael (2006): The New East End. Kinship, Race and Conflict. Profile Books, London.

· Frykman, Jonas (1991): Klassresenären lever i exil, i Molin, Kari og Ågren, Britt (red.): Klassresan. Alfabeta Bokförlag, Malmö.

- Gullestad, Marianne (2002): Det norske set med nye øjne. Universitetsforlaget, Oslo.

- Hey, Valerie (2003): Joining the Club: academia and working class femininities, in Gender and Education 15 (2).

- hooks, bell (1997): Wounds of Passion. A Writing Life. The Women's Press, London.

- Jacobsen, Lis (red.) (1925): Kvindelige akademikere 1875-1925. København.

- Mahony, Pat and Zmroczek, Christine (eds.) (1997): Class Matters: 'Working-Class' Women's Perspective on Social Class. Taylor \& Francis, London.

- Manniche, Jens Christian (1983-1985): Danske historikere 1864-1940. Historie XV.

- Mørck, Yvonne (2003): Narratives of the intersections of masculinities and ethnicities in a Danish high school class, i NORA. Nordic Journal of

Women's Studies no.2, vol.11.

- Mørck, Yvonne (2006): Why not intersectionality? A concept at work in modern complex societies. Intersectionality and class travels. Freia, Aalborg University, Paper 61 (www.ihis.aau.dk/freia/index.php). - Mørck, Yvonne (2008): Komplekse rejser, i Ungdomsforskning Nr.1 \& 2, Årgang 7. Center for Ungdomsforskning, DPU/Aarhus Universitet. - Mørck, Yvonne (2009): Complex Travels: Class Travellers and (Critically) Multicultural Education in Relation to the Danish Upper-Secondary School, i Selander, Staffan \& Aamotsbakken, Bente (eds.) Nordic Identities in Transition. Novus Forlag, Oslo.

· Putnam, Robert D. (2007): E Pluribus Unum: 
Diversity and Community in the Twenty-first Century, in Scandinavian Political Studies Vol.20, No.2. - Rosenbeck, Bente (2008): Har videnskaben køn? Upubliceret manus.

- Skeggs, Beverly (1997): Classifying Practices: Representations, Capitals and Recognitions, in Mahony, Pat \& Zmroczek, Christine (eds.): Class Matters: 'Working-Class' Women's Perspective on Social Class.Taylor \& Francis, London.

- Trondman, Mats (1994): Bilden av en klassresa. Sexton arbetarklassbarn på väg till och $i$ högskolan. Carlsson Bokförlag, Stockholm.

- Young, Michael \& Willmott, Peter (1990): Family and Kinship in East London. Penguin Books, London/Middlesex (org. 1957).

- Wennerström, Ulla-Brit (2003): Den kvinnliga klassresan. Göteborg Studies in Sociology no. 19, Göteborg.

\section{SUMmary}

Travels and change: Intersections of class, gender and ethnicity

The article presents and discusses various aspects of the 'class travel' concept. It begins with a description of the class journey into Academia undertaken by two contemporary women. A female 'gender travel' is exemplified by the first female academics to study at Copenhagen University in 1875. A group of girls from the 1950s East End of London, who received a longer schooling, represents both a class and gender journey. In the 'New East End' in the 1990s, however, ethnicity is in focus - in intersection with class and gender. The aim of this contribution is to illuminate the interweaving of gender, class and ethnicity in both a historical and contemporary perspective in relation to education on all levels.

Yvonne Mørck

lektor ved Institut for Samfund og Globalisering Roskilde Universitet

Bente Rosenbeck professor ved Center for kønsforskning Københavns Universitet 